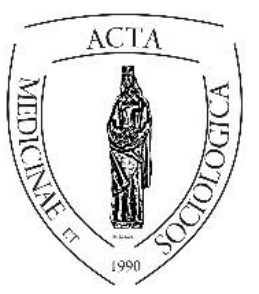

Acta Medicinae et Sociologica (2021)

Vol. 12. No. 32. (5-23)

UNIVERSITY OF

DEBRECEN

doi:

FACULTY OF

HEALTH

https://doi.org/10.19055/ams.2021.05/31/1 NYÍREGYHÁZA

\title{
A húsvéti járvány - a COVID-19 várható hatásai az Euro-atlanti tér társadalmaira
}

\section{Bódi Ferenc ${ }^{1}$}

${ }^{1}$ Bódi Ferenc Társadalomtudományi Kutatóközpont, Politikatudományi Intézet, Budapest, tudományos főmunkatársa, az EURISPES, Róma, külső munkatársa, a Storia e Futuro, Firenze szerkesztőbizottságának és a Turati Foundation, Firenze, tudományos testületének a tagja.

\section{INFO ABSTRACT}

\section{Bódi Ferenc}

Bodi.Ferenc@tk.hu

\section{Keywords}

health care, security policy, crises, social policy, epidemics, social change
The purpose of this article is to estimate the changes caused by the COVID-19 pandemic for healthcare and the medical industry that serves it. Furthermore, an estimate of the expected impact of the epidemic onto economic and social change. In addition, to estimate the expected impact of the epidemic on economic and social changes. The article was written in two different periods. The first part ended in April 2020 and the second part in April 2021. The article is essentially a thought experiment. A reasoning enclosed in a bottled mail that the author rewrote after a year in the light of the changing facts. The article concludes that COVID-19 will help complete a long economic cycle. This crisis accelerates a technological shift in which creative destruction occurs in the economic subsystem as well as in other subsystems of the society. The new long economic cycle (Cycle K), just as it happened after World War II, builds a new social quality. At the beginning of the new $\mathrm{K}$ cycle, the former welfare state model is replaced by a wellbeing society concept. The basis of a wellbeing society will be solidarity, cooperation and quality. For the individual, health will no longer be just an optional lifestyle, but an effective form of survival.

\footnotetext{
${ }^{1}$ Bódi Ferenc Társadalomtudományi Kutatóközpont, Politikatudományi Intézet, Budapest, tudományos fömunkatársa, az EURISPES, Róma, külső munkatársa, a Storia e Futuro, Firenze szerkesztőbizottságának és a Turati Foundation, Firenze, tudományos testületének a tagja.
} 


\section{Kulcsszavak}

egészségügy, biztonságpolitika, válságok, szociálpolitika, járványok, társadalmi változás
A cikk szándéka a COVID-19 világjárvány okozta változások becslése az egészségügyre és az azt kiszolgáló egészségiparra, továbbá a járvány várható hatásának becslése a gazdasági- és társadalmi változásokra. A cikk két különböző időben íródott. $\mathrm{Az}$ első rész 2020 áprilisában-, a második rész 2021 áprilisában zárult. A cikk lényegében egy gondolatkísérlet. Egy palackpostába zárt okfejtés, amelyet a szerző felülbírált egy év után a változó tények ismeretében. A cikk következtetése szerint a COVID-19 egy hosszú gazdasági ciklust segít lezárni. Ez a válság egy technológiai váltást gyorsít fel, amelynek során a gazdasági alrendszerben, valamint a társadalom más alrendszereiben is kreatív rombolás következik be. Az új gazdasági hosszú ciklus ( $\mathrm{K}$ ciklus), mint az történt a második világháború után, egy új társadalmi minőséget épít fel. Az új K ciklus elején a korábbi jóléti állammodellt egy jólléti társadalom-koncepció váltja le. A jólléti társadalom alapja a szolidaritás, az együttműködés és a minőség lesz. Az egyén számára az egészség már nem csak választható életforma, hanem a túlélés egy hatékony formája lesz.

\section{Az „első húsvét”, 2020 húsvétja}

A húsvét, a feltámadás misztériuma, a megvilágosodás lehetőségét is magába rejti, s mint Goethe Faustját a húsvéti harangok hangja életben tart minket, s ráeszmélhetünk önmagunk új belső világára. A húsvét most az Euro-atlanti térre (Észak-Amerika, Európa, Oroszország) egy olyan járvány idején köszöntött, amikor a nagyvárosok kihaltak, a tömegek eltűntek, naponta ezrével járó géppárok a földre kényszerültek, a civilizációnk egy pillanatra megállt, elcsendesült.

Az új kor eddigi legnagyobb hatású járványa kényszerítette ki ezt a cseppnyi csendet. Épp százkét éve a H1N1 vírus okozta (nem pontosan detektált vírus) járvány; a spanyolnáthahatása volt talán ehhez hasonlítható, amely akkor lényegében a világ népességének 3-5 százalékét pusztította el (Johnson és Mueller, 2002). A mostani ragály reményeink szerint kevesebb áldozatot követel, de hatása minden bizonnyal nagyobb lesz, mint ami akkor a világon végig söpört.

A járványokat tekinthetjük biológiai szelekciónak is, Isaac Bashevis Singer Nobel-díjas író életrajzi regényében írja a Varsóban töltött kora harmincas évekre visszatekintve; a zsidó vallás a háborút, az éhínséget és népességet tizedelö járványokra, mint Isten csapására tekintett, lényegében ezt az emberi 
létezés természetének tartja, s ebben osztozik a keresztény világnézet is, amely János jelenései között a dögvészt az egyik apokalipszis csapásként jeleníti meg. ${ }^{2}$

A járványok a történelmet erőteljesen formálták, jelentős fordulópontokat és átmeneteket képeztek egy-egy új korszak számára. Az 1346-1349-es pestis, becslések szerint Európa népességének felét vitte el, ez az apokaliptikus járvány munkaerőhiányt eredményezett. A munkaerő ára jelentősen megemelkedett, $\mathrm{s}$ ez jelentős technikai fejlődést indított el, $\mathrm{s}$ ami még ennél is fontosabb volt, megindult az oktatásban a praktikus ismereteknek a széles körben való terjedése. Lényegében megkezdődött a modern tudományok kifejlődése az ókori kultúra alapjain, Európára ráköszöntött a reneszánsz, amely utat nyitott a modernitás felé (Ferguson 2011). Vagy tekintsünk a 1666os Londoni tüzvészre és azt megelőző pestisre. A ma ismert városszerkezet ezután, az apokaliptikus évek után jött létre (Defoe 1978).

Az 1708-as magyarországi pestis járvány nagyobb humán veszteséggel járt, mint az azt megelőző sikeres törökellenes háború (1684-1699), és azt követő szabadságharc (1703-1711) együttvéve. A gyérnépességủ országba megindul a szervezett betelepités a 18. század egészében, amely így nyelvileg sokszínü népességü országot eredményezett, illetve erősített meg (Wellmann 1989). S ebben a demográfiai vákuumban fejlödött ki az Európában egyedül álló vallási sokszínüség és oktatási szabadság, amely megvetette az alapjait a reformkornak, a modernkori Magyarországnak, amelynek gyermekei ebből az oktatási rendszerben nőttek fel (Kosáry 1983, 1991).

Történelmi példák tucatjait hozhatnánk fel, amelyben a járványok és az ezt követő válságok gyakran nyitották az utat egy-egy új korszak felé. Azonban látnunk kell, a tragédiák nem elegendőek a megújuláshoz, mert az esetek többségében a fejlődéshez szükség volt az oktatási rendszerek megújulására, s azok szabadságára is. Reménykedünk, az új koronavírus okozta járványnak kevesebb áldozata lesz, de hatása minden bizonnyal tartósabb lesz, mint az első világháborút lezáró vésznek. A hatások, prima facie, a következőkben jelezhetők elöre az Euro-atlanti térségben:

1. A koronavírus okozta járvány hatásaként az egészségügy prioritásait megváltoztathatja, azaz korábban a kardiovaszkuláris betegség

\footnotetext{
${ }^{2}$ „Amikor feltörte a negyedik pecsétet, hallottam a negyedik élőlény hangját, amint így szól: Jöjj! És láttam: íme, egy fakó ló, a rajta ülőnek neve Halál, és a Pokol követte őt; és hatalom adatott nekik a föld negyedrészén, hogy öljenek karddal, éhínséggel, döghalállal és a föld vadállatai által." A jelenések könyve 6 (7-8).
} 
(Cardiovascular disease, CVD) és onkológiai prioritások mellé a járványok elleni védekezés felzárkózik, különösen azért is, mert az utóbbi betegségcsoport diagnosztikai eredményei több kapcsolatot feltételeznek a ragályos betegségekkel. ${ }^{3}$ Ez a hatás lényegében hasonló lesz, mint volt száz éve, amikor a spanyolnátha után az említett geopolitikai térben a járványügy az egészségügyi rendszerekben jelentős politikai támogatást kapott. Például Magyarországon az első világháború után indult el hatékonyan a gümökór vagy tuberkulózis (tbc) elleni harc, ${ }^{4}$ vagy láthatunk példát arra is, hogy egy járványos betegség lényegében megszünik, ilyen volt a veszettség ${ }^{5}$, a védőoltásoknak köszönhetően. A járványügy felértékelődése, s ehhez kapcsolódó kutatások és oltóanyagok fejlesztése jelentősen hozzájárultak a várható élettartam növekedéséhez, lényegében egy jobb életminőség kialakulásához a centrumban, s az ehhez felzárkózni igyekvő országokban. Az emberek élete nem csak hosszabb, de jobb is lett, hiszen kevesebbet lettek betegek, mivel kevesebben betegedtek meg és nem kellett viselniük a járványos megbetegedés okozta szövődményeket sem, gyakran élethosszig tartó szövődményeket (pl. spanyolnátha okozta neurológiai szövődmények). A fejlett világ ezáltal még fejlettebb és még erősebb lett, mint valaha. Az ENSZ statisztikái szerint az emberiség lélekszáma az Egyesült Államok megalapításakor egy milliárd fő lehetett, amely a második világháború előtti évekre duplázódott meg, de már 2019ben meghaladta a 7 milliárd föt. Ehhez a népesség robbanáshoz a modern járványügy, s az ehhez kapcsolódó vakcina-kutatások, továbbá a higiénia feltételeinek megteremtése, alapvetően a civilizáció fejlődése nagymértékben hozzájárultak. Csak Magyarországon a várható élettartam 1920 és 1960 között majd megduplázódott, amelyben nagy szerepet kapott a védönöi szolgálat felállítása és ennek hatásaként a csecsemö- és gyermekhalandóság radikális visszaszorulása, amelyet lényegben a ragályos megbetegedések visszaszorulása okozott (Bódi 2012, 2014). A népesedési dinamika a 20. század közepén az Euro-atlanti térről Ázsiára tevődött át. Az ezredfordulót követően pedig az afrikai kontinens

\footnotetext{
${ }^{3}$ Helicobacter pylori, hepatitis B, hepatitis C, human papillomavirus, Epstein-Barr virus és human immunodeficiency virus (HIV), stb.

${ }^{4}$ 1940-ben Johan Béla, az egészségügy államtitkári rangú vezetője kezdeményezte az első tuberkulózis elleni törvényeket.

${ }^{5}$ A veszettség elleni küzdelmet Eucharisztikus világkongresszusra készülő ország kampányszerüen szorította vissza, ez ugyan is a Vatikán egyik feltétele volt, amelyet a világesemény megrendezőinek vállalni kellett 1938-ra.
} 
népesedési dinamikája gyorsult fel. Jelen századunk végére az ENSZ-nek a Föld népességére vonatkozó előrejelzése szerint Afrika népessége Ázsia népességét megközelíti. A népesség változását sok tényező befolyásolja, egyik faktor a halálozási ráta, $\mathrm{s}$ az azt befolyásoló tényezők. A modern kor vitathatatlan vívmánya a ragályos betegségek elleni védekezés, illetve azok ellenei preventív rendszerek megerősödése. Az új koronavírus okozta epidémia ezt a védekező reflexet újra felerősíti, s valószínüsíthető az egészség-politikák fókuszába régi presztízsében visszaállítja a járványügyet. Az új koronavírus megjelenése, s az ezt követő politikai cselekvésben megjelenő sokkszerü reakció, ahhoz hasonló, amikor egy vakcina stimulálja az emberi szervezet immunrendszerét az ellenanyag termelésre. A COVID-19 egy ilyen emlékeztető oltásként értelmezhető, azaz egy olyan sokk a társadalmak életében, amely felrázza azok védekező ösztönét. A spanyolnátha után kitört más járványok ezt a sokkot nem érték el, sem a súlyosabb ebola vérzéses láz, vagy a már epidémiát okozó HIV sem, mert ezek a járványok lényegében izoláltak voltak, vagy földrajzi területre (Nyugat-Afrika, Ebola folyó völgy járványgóc), vagy társadalmi rétegekre korlátozódtak, vagy azokra vonatkoztatták (szexuális úton terjedő betegségek). Az új koronavírus sajátsága az, hogy hatékonyan terjed, társadalmi rétegek szempontjából nem specifikus és különösen az öregedő társadalmakra, így az Euro-atlanti tér politikai rendszereire sokkolóan hat és minden bizonnyal fog hatni. Különösen erös lesz ez a stimulálás, ha felerősödnek azok a vélemények, amelyek újabb világjárványok megjelenését vetítik előre (Barabási 2018).

2. A védekező mechanizmus, ha túl radikális, akkor önmagában az immunmechanizmus blokkolhatja az egészséges szervezetet. Ilyen hatása lehet annak, ha egy válságot egy szervezet, vagy intézmény túlreagál, $\mathrm{s}$ emiatt kerül valóban válságba. Vannak vélemények, miszerint a társadalmak túlreagálják a jelen járványügyi helyzetet, $\mathrm{s}$ ez a védekező cselekvés önmagában társadalmi és gazdasági válságot idéz elő. ${ }^{6}$ Persze jelen ismereteink hiányosak, ténylegesen nem tudható pontosan, hogy a járványt okozó vírus, illetve vírustörzs hatása milyen az emberre s annak milyen szövődményei lehetnek. Megjelentek olyan orvosi szakvélemények, amelyek arról adnak hírt, hogy tünetmentes

\footnotetext{
${ }^{6}$ https://swprs.org/a-swiss-doctor-on-covid-

19/?fbclid=IwAR12hv1VdEIZWYTPqvr0ABCUiFXhqzw5oiq5S-P5CgxNINa7EwznQMF2cuo
} 
koronavírusos betegeknél jelentős tüdőkárosodást állapítanak meg, azaz a betegség jellemzőit és annak biológiai következményeit lényegében még csak most kezdjük megismerni ${ }^{7}$.

Tehát a társadalmak ,,autoimmun” reakciója csak feltételezhető - ha mégis így lesz, akkor a járvány áldozatainak közvetlen számát minden bizonnyal meg fogja haladni azon áldozatok száma, akiknek a halálát az egészségügy normál leállása okozza, továbbá azok a gazdasági hatások, amelyeket az emberek jövedelem vesztesége, nota bene, egzisztenciák tönkre menetele idéz majd elő. Ha viszont a társadalmak, illetve az azokért felelős politikák nem lesznek kellően elörelátók és magas mortalitási mutatók lesznek, vagy és a járvány okozta másodlagos megbetegedések száma lesz túl magas, akkor azok, akik az intézkedéseket hozták, illetve nem hozták, kerülnek a kritikák kereszttüzébe. Minden esetre az tény, nehéz ma jó politikát kialakítani. Nehéz az Arisztotelészi középet eltalálni. Ha erösek az intézkedések, akkor a politika túllő a célon, ha cselekvése gyenge, akkor magát a célt nem éri el. Ebben a helyzetben a Nikomakhoszi etikában lefektet középértéket, mint erényes cselekvést nehéz megvalósítani, ezért a vírus okozta járvány egyes kormányzatokat majd felmagasztal, másokat majd elmarasztal (Bódi 2020a). Egy biztos, nem nehéz előre jelezni, hogy a COVID-19 a jövő politikai vitáinak napirendjét erőteljesen meg fogja határozni. Persze az értékelés és kritika nem csak kormányzat és ellenzék dimenziói mentén lesz értelmezhető, hanem a különböző kormányzati stílusok között is. A politika hatalomgyakorlás és ezen belül válságkezelési módszertanok értelmezése - minden bizonnyal egy darabig slágertéma lesz a politológiában és politográfiában, azaz az újságírásba hajló politikaértelmezésben. Ami igazán tanulságos lenne, az kevésbé lesz publikus, mivel azok az értékelő panelek már az agytrösztökben és a titkosszolgálatokban kerülnek feldolgozásra, ezek termékei azok a modellek lesznek, amelyekben egy-egy háborús helyzet vagy egy-egy tömegkatasztrófa helyzeteit szimulálják. Ma egy nagy laboratóriummá vált a világ - dolgoznak a számítógépek és készülnek a válságmodellek, egy biztos, itt nem fognak eredményt hirdetni, bár ezekböl lehetne tanulni. Az új biztonságpolitikai modellek átrendezik a biztonságpolitikai stratégiákat. Az egyéni és az egy pontra lesújtó terrortámadás fenyegetése mellé felzárkózik a tömegeket érintő és nagy területre kiterjedő terrorfenyegetés elleni

\footnotetext{
${ }^{7}$ https://www.rainews.it/tgr/tagesschau/articoli/2020/04/tag-Coronavirus-LungeschadenForschung-Uniklinik-Innsbruck-6708e11e-28dc-4843-a760-e7f926ace61c.html
} 
védekezés is, amelynek „fénykora” a hidegháború időszakában volt. Minden bizonnyal a hidegháború korát idéző percepciók a biztonságpolitikai retorikában és cselekvésben visszatérnek, s ennek a „lehülésnek” lehet átmeneti hatása a nemzetközi diplomáciára és bizonyos formában a most kibontakozódó kereskedelmi- ipari- és informatikai háborúra is, amely az Euro-atlanti térség államainak jövőjét erősen befolyásolhatja.

3. Kiválthatja-e a globális rendszerek revízióját a Kínából induló világjárvány, amely néhány hét alatt az Euro-atlanti légtér forgalmát 10\%-ra csökkentette? Amely nemzetgazdaságok gyors leállását, vészfékezését idézte elő, magas munkanélküliséget és gazdasági visszaesést okozva. Ez nem hihető, mivel a járvány elülte után, $\mathrm{s}$ azt követő esetleges utóhullámai után a világ visszakerül korábbi kerékvágásába. A globálisméretü üzleti érdekek és ezzel összefonódott politikai alkuk nem engedhetik a korábbi hálózatok felbomlását. A világgazdaság útfüggősége nem bomlik fel. Ha majd ki is billen ebből a kerékvágásból, azt elhagyni csak egy történelmi léptékủ idő alatt tudja megtenni. Hiú remény, ha azt gondoljuk, hogy a járvány okozta gazdasági sokk felrázza az emberiséget és ezután a termékpályák rövidítésén dolgoznának, s ezzel a helyi, vagy nemzeti piacok megerösödnének a globális befolyással szemben. Ott, ahol rezisztens volt a helyi piac, nyilvánvalóan az erősebb szereplő lesz, de ott ahol ez nem épült ki az elmúlt évtizedekben, ott nem fog az a semmiböl létrejönni. A fogyasztást irányító média és a fogyasztói magatartást formáló nevelés, illetve az ezeket is formáló oktatási rendszerek lassú változása azonban beindulhat. Amennyiben elfogadjuk a Kondratyjev-ciklus (K-hullám) létezését a makroökonómiában, akkor feltételezhetjük azt is, hogy a jövő nemzedék fogyasztása, ezáltal a viszonya a piachoz változni fog (Bródy 2007). Lásd például, ma a szórakoztató tartalmak nem hardverek útján, hanem inkább, a virtuális térben, a neten terjednek. Ez egy tanulási folyamat eredménye. A K-hullám okozta ciklusváltásnak, s annak eredményeképpen létrejövő új gazdasági szerkezetnek az előre jelzése nem egyszerü feladat. Nem tudjuk, mi lesz a jövő meghatározó energiaforrása, $\mathrm{s}$ az milyen technológiai váltást eredményez (megújuló hidrogén alapú, atomenergia, vagy hibridforrás), továbbá mikor tetőzik a ciklus, valamint milyen gyors lesz a váltás.

4. Felvetődik, a világ magába zárul és csökken a személyes kontaktusok száma, kevesebbet utazunk és inkább helyi termékeket fogyasztunk. Ez sem valószínü, mivel a komplex technológiák alkalmazása globálisméretü termelési hálózatokat indokol. Mi magunk is, ha egy könyvet szerkesztünk 
például Firenzében, $\mathrm{s}$ a társszerzőink Portugáliában, az Egyesült Államokban és más országokban vannak, s ezt mi Budapestről szervezzük, egy komplex rendszert használunk, ez az internet. Egy szakkönyv egy ilyen komplex termék, amelyet végül is egy olasz szerkesztőség önt végső formába. Ettől lényegesen bonyolultabb egy müszaki termék, amelyen sok fejlesztő és technikus dolgozik, de nem lehet mindenki egy helyen és az alkatrészek sem kell, hogy egy helyen készüljenek. Például a jármüipar, s ennek élén a repülögépgyártás egy országon belül ma már nem szervezhető meg. Ma a világ termelésének nagy részét komplex hálózatok állítják elő, kevés olyan termék van, amelyet egy nemzet lenne képes gyártani, még a legféltettebb hadiipari, nukleáris, valamint ürtechnológiák sem nélkülözhetik a nemzetközi együttműködést. A tömegtermelésben előállított mindennapi fogyasztási javak is bonyolult logisztikai hálózatokon keresztül utazzák át a Földet. Ez utóbbinak nincs technológiai indoka, de annál inkább erösebb kereskedelmi és üzleti érdek található meg mögötte. A világon nem lehetne utazni olyan áron és minőségben, ha ezt nem támogatná ilyen mértékü áruforgalom. Az árutömeget mozgató sodorvonalon utazik több millió turista is, aki ostoba módon fényképezi magát az Uffiziben vagy épp az Akropoliszon anélkül, hogy tudná ki volt Lorenzo de' Medici vagy Periklész. Ezt a fogyasztási folyamatot még egy apokaliptikus világjárvány sem állítaná meg. Legfeljebb korunk tömegutazói, a turisták a tömegsírok előtt is ellőnének egy-két képet magukról. A változás - sejtésem szerint lassú lesz, de annál maradandóbb. A változást a tanulórendszereknek tekinthető tudományos percepciók nyithatják meg, amelynek eredményei lecsurognak az oktatási intézményekbe. A tudásverseny révén a világnak egy új értelmezési kerete erősödik meg, amely lassan átcsap a korábbi nézetek terelőgátjain és az új tudás folyama egy új medret váj a régi helyébe. Ez a tudás egy olyan oktatási forradalomban terjedhet el, mint ami például volt a 14. századi európai egyetemeken Bolognában, Padovában, a Sorbonne-n és Oxfordban, valamint Córdobában és a progresszió más bölcsőjében, itt Európában (Le Goff 2000). Akkor a régi- és új tudás létrehozta a modernkort és az Euro-atlanti tér lényegében bekebelezte a világ más területeit. Hasonló tudás,- illetve oktatási forradalom történt a 18. században Magyarországon is, amely megteremtette a reformkort, s a 19. századi modernizáció alapjait (Bódi 2020b).

Hasonlóan a korábbi korszakváltásokhoz, a jelen globális világa is egy gigantikus ciklusváltásba került most a 21 . század első harmadában. 
Amennyiben a megjelenő új technológiák és új szemléletek úgy formálják a világot, hogy abban felértékelödik a minöség a mennyiséggel, az egyediség a tömeggel, valamint a lokális a globálissal szemben, akkor lehet változás és megtörik a jelen kor útfüggösége. Ez lenne a minöség forradalma, amelyben érzékenyebbek lehetünk önnön saját belső világunkra és mások értékrendjére is. Hatékonyabb lenne a világ, ha megváltozna a célok, és az azokat elérő eszközök rendszere. Talán kevesebbet kellene utaznunk, hogy elérjük a célunkat és utaztatni munkánk eredményét, hogy az áruként célt érjen. Több időt tölthetnénk saját környezetünk megismerésével, s egyben jobban megismerhetnénk önmagunkat. A világ mikro-szinten jobban kitágulna, amely elvezetne a létezés, a távlatok, a jövő jobb megértéséhez. Az új világot egy belső változás indíthatja el a tudás és tanulás révén, amelyhez ez a járvány és az ennek okán fellépő válság bennünket hozzásegít.

Összességében véleményem szerint az egészségipar és egészségpolitika jelentős változás elött áll a COVID-19 következtében. A ragályos betegségek és az ezek elleni védekezés valamint a diagnosztikai kutatás és technológiák minden bizonnyal nagyobb fejlődés elött állnak, mint korábban. A világjárvány ösztönzést adhat a nagyobb és átfogóbb kutatási együttmüködéseknek és programoknak, amelyben a kormányzatok mellett nemzetközi szervezeteknek és az egészségipar vezető cégeinek valamint intézeteinek óriási szerep jut.

Továbbá a biztonságpolitikai rendszerek fejlödését is ösztönözheti az új világjárvány, miután 2001. szeptember 11-e után a nagy területeket érintő támadások elleni védekezés ügye némileg háttérben szorult - lényegében a hidegháború végével elindult ez a hanyatlás, viszont most nagyobb súlyt kapnak a hagyományos polgárvédelemi feladatok (vegyvédelem, biológiai védelem, stb.). Most lehetséges, hogy a tömegeket és nagy területeket érintő támadások elleni védekezés technikáit és módszereit jobban igyekeznek fejleszteni.

A világgazdaságra jósolt nagy változásokban kételkedem, mivel ehhez egy jelentős társadalmi tudat átformálódás is kellene, amelyhez ez a sokk nem elegendő. Ha változás lesz, az minden bizonnyal a tömegmédia, az oktatási és a nevelési rendszerek egészének változásával kezdődhet el. A fogyasztást és a társadalmi szükségleteket azok a fogyasztói magatartások vezérlik, amelyeket a tömegmédia befolyásol. A piacok, és erre épülő logisztikai hálózatok uralma nem fog egyik pillanatról a másikra megtörni 
és átrendeződni, ebben túl sok az érdek és érdek összefonódás, hogy azt bár milyen nemzeti- vagy lokálisforradalom felbontaná. De várható változás, $\mathrm{s}$ ez minden bizonnyal lassú transzformáció lesz, hasonlóan a spanyolnátha utáni időszakra, amely közel egy emberöltő alatt tudott látványos eredményt elérni. Ez egyfajta oktatási forradalom lehet, amelyet egy új nemzedék készíthet elö.

2020. április

\section{Egy év után ismét a „húsvéti járvány” - a COVID-19 várható hatásai az Euro-atlanti tér társadalmaira (2021. március)}

Most a járvány harmadik hullámában újragondolom az egy évvel ezelőtt papírra vetett sorokat. 2020-ban négy pontban foglaltam össze mondandómat, most ezt a négy témát folytatom tovább: egészségipar, válságkezelö politika, globálisgazdaság, társadalmi változás.

1. Egy év után, 2021 tavaszán egyértelmüen látható az egészségügyi ipar óriásainak a részvényei felfelé íveltek. A kutatás és fejlesztés a fertőző betegségekre és ezen belül a koronavírus kutatásokra fokuszált. A globális térben kialakult egy erőteljes verseny, amely a WHO koordinációt is megkerülve, korábban nem látott versenyfutást eredményezett a multinacionális cégek között a presztízsért, a profitért. Láthatóvá váltak a nagy nemzetközi megállapodások gyenge pontjai és a nemezközi koalíciókon megjelentek a repedések. Az államok saját érdekei előtérbe kerültek, a partnerek és szövetségesek rovására. Tavaly még az egészségügyi felszerelésekért és eszközökért folyt a harc, most az oltóanyagok beszerzésért folyik a küzdelem, mivel az államok kormányai felelnek a kialakult helyzetért. A közelgő választások jelentős nyomás alá helyezték a kormányzó pártokat a demokratikus rendszerekben. A jövőben, minden bizonnyal az egészségügyi szolgáltatások- és ellátórendszerek, az általános és szakellátás, valamint a járóbeteg és fekvőbeteg ellátás felértékelődik. Az orvosi és ápoló személyzet, mint láttuk, a járvány idején a média érdeklödésének a középpontjába került. 2020-ban tapssal köszönték még meg az egészségügyiek munkáját, világszerte szíveket tettek az ablakokba tiszteletükre, mára ez a lelkesedés kifulladt. Azonban a jövőben az egészségügyért felelös politikákban az egészségügyi szektor minden bizonnyal nagyobb prioritást kap. Ennek a jelét tapasztalhatjuk Magyarországon az egészségügyi ágazati béremelés bejelentésével. Ugyanakkor a média fókuszába kerülésnek lehetnek veszélyei is. A 
hősökből gyakran lehetnek bủnbakok is. Azaz a tehetetlenségért, amelyet a járvány okoz, közvetlenül azokat tehetik felelőssé, akik ez ellen közvetlenül teszik a dolgukat. Ez olyan, mint amikor a háborúvesztésért, nem a konfliktusért felelős politikusok kerülnek a célkeresztbe, hanem az annak következményeként háborút viselő katonák. Csak remélhetjük ezt a háborút az Euro-atlanti tér megnyeri, de legalábbis az államok többsége túléli anélkül, hogy súlyos árat kellene fizetnie ezért.

Egy év után ez jól látható. A szervezetek, így köztük az államok vonatkozásában a szolidaritás nem erösödött, inkább gyengült az Európai Unióban. Az lett ebben a válságban eredményesebb, aki gyorsan és magában ért el eredményt, s ezt úgy érte el, hogy másokra kevésbé volt figyelemmel. Egy-két látványos segítségnyújtáson kívül lényegében minden tagállam saját forgatókönyvet alkalmazott és eredményeit is nemzeti szinteken igyekezett maximalizálni. Látható ez 2021 tavaszán. Az egészségügyi rendszerek paradigmatikus átszervezésének jelei még kevésbé láthatóak, inkább az ad-hoc megoldások domináltak. A nemzeti szintủ megoldások kerültek elötérbe, a kollektív cselekvés kínálta megoldásokkal szemben. Ezt látszik bizonyítani az a tény is, hogy az Európai Unió nem tudta kihasználni a közös vakcina beszerzés előnyeit, így jelentős időt vesztett az Egyesült Államokkal és az Egyesült Királysággal szemben. Az új olasz kormány ennek következtében azonnal az oroszokkal közös vakcina gyártásról írt alá megállapodást. A külön utas megoldást preferálta Magyarország is, amikor a kínai és orosz beszerzést megnyitotta. A szlovákoknál kormányválságot idézett elő az orosz vakcina behozatal. A COVID-19 járvány rámutatott az Euro-atlanti tér érdekmezőinek valós érdekhálózatára. Az Egyesült Államokban hatalomra jutott, Biden adminisztráció a vakcina hiánnyal küzdő EU-t nem volt hajlandó megsegíteni átmeneti szállítmányokkal sem az állami biztonsági tartalékokból. Az EU számára az sem adhat vigaszt, hogy Washington nem csak az európai szövetségeseivel volt fukar, de közvetlen szomszédaival is. Így Mexikónak és Kanadának is a kontinensen kívülről kellett keresni vakcina beszállítókat.

Felvetődik a kérdés, hogy egy nagyobb mortalitással bíró világjárvány vagy más nemzetközi válság esetén, vajon milyen forgatókönyveket alkalmaznának az államok? Az sejthetö, hogy a vészhelyzeti forgatókönyvek az államok szintjén, lényegében az adott politikai érától függetlenül lépnek életbe egy adott riasztási szinten. Az államok önös érdekei felülírják a közös cselekvés stratégiáját, akkor is, ha azokra korábban 
elkötelezték magukat, de még abban az esetben is, ha a közös cselekvés a lehetséges együttmüködők mindegyikének nagyobb hasznot adna, mint amit elérnek külön-külön. Ha a járványkezelésre, mint egy globális méretü tesztre tekintünk, akkor megállapítható, a kölcsönösség és együttmüködés kudarcot vallott az Euro-atlanti tér összetett érdekrendszereiben, mint a WHO, az Egyesült Nemzetek, mint a NATO, mint az EU rendszerein belül. A nemzetek, illetve az államok szintjén a politikai eredményesség kérdése a válságot követő választások után jöhet szóba.

2. A járványügyi intézkedések gazdasági hatása, s azt követő talpra állás, illetve talpra állítás, a második világháború óta nem látott kihívás elé állítja a nemzetgazdaságokat és az azokat alakító gazdaságpolitikák alakítóit. Az államadóság az EU tagországokban megugrott, messze meghaladta 2020ban a pénzügyi stabilitás elvárta küszöbértékeit, különösen a mediterrán térség országaiban, ezzel együtt a nemzetgazdaságok teljesítménye csökkent a tagállamok mindegyikében. A járvány előidézte gazdasági válság, a járvány végeztével magától nem csitul. A munkahelyvesztés, amelyet a turizmus, a jármügyártás visszaesése idézett elö, hatással van a mezőgazdasági beszállítókra, a kisvállalkozások tízezreire, amelyek, ha nem kaptak volna állami mentöövet, akkor végleg tönkre mentek volna. A gazdasági intervenciók és belső támogatások felduzzasztották az államok költségvetési hiányát. Az államháztartási hiányt hitellel pótolják, amely újabb és újabb hitelfelvételt eredményez. A romló államháztartási mutatók miatt romló hitelfelvételi feltételek mellett, azaz növekvő kamatok mellett tudnak az adósságcsapdába jutott országok hitelhez jutni. A déli államok eladósodását az északi államok nem fogadták lelkesedéssel, ezt már Görögország esetében tapasztaltuk a 2008-as válság utáni években, ez a feszültség végük is csökkenti az államok közötti szolidaritást az Európai Unióban.

A válságkezelésére az EU eddig sosem látott pénzügyi lépésre szánta el magát, hitelhez folyamodott. A helyreállitási hitelcsomag olyan pénzmennyiség, mintha a 2019-es, utolsó békeév, EU gazdaság éves összteljesítmény értékének a felét megkapnák a tagállamok egy összegben. A kérdés az, hogy a helyreállítási hitelcsomag 750 milliárd eurós eszközalapja okozta többletet, a korábbi gazdasági szerkezet helyreállítására költik, vagy jelentős szerkezet átalakításra is jut ebből? A válság egy schumpeteri kreatív rombolás utáni újgazdasági szerkezetnek ad teret, amely energia- és nyersanyag- és munkaerő kímélőbb lesz, vagy visszaépíti a régi 
gazdasági szerkezetet, annak gyengeségeivel és kitettségével? Vajon mennyire ad teret kreativitásnak az újjáépítés? Ezekre a választ nemzetgazdasági keretek között adják meg. Amíg a hitel kockázat közös, addig annak a forrásfelhasználás eredményessége nemzeti keretek között lesz mérhető. Megindul a versenyfutás az idővel, amely országok hamarabb nyitnak és a hitel nyújtotta többletforrást hatékonyan tudják felhasználni, azok jelentős előnyre tesznek szert. Amíg más országok nem tudnak korán nyitni, és külső forrásaik jelentős részét saját politikai túlélésükre fordítják, azok jelentős hátrányba kerülnek. Azok lehetnek eséllyel sikeresek, amelyek a globális gazdaság okozta kitettségre lokális válaszokat tudnak adni úgy, hogy azt a globális piacok is elfogadják. Ennek egyik útja, ha a váratlan jövedelem (windfall gain) okozta forrás felszívás nem a hagyományos szektorokba, hanem a hitel adta többletforrások a lokális lehetőségekre építő, nemzetközi piacokon is versenyképes termékek exportját növelő gazdaságba kerül. Ezek a termékek lehetnek immateriális javak, szellemi termékek, fejlesztések, innovációk, tudás, szolgáltatások, találmányok, szoftverek, amelyeknek az előállítása nem igényel magas anyag és energia hányadot. Ez lehet, például az egészségügy, rehabilitáció, rekreáció és olyan szolgáltatás, amely egy elöregedö térségben jelentös hasznot hoz, valamint a hozzáadott tudás hányada magas. A romok alá került turizmus, minden bizonnyal újra indul, de minden bizonnyal nem a régi formában. Egy éve még azt mertem gondolni, a tömegturizmus újra indul és a tömegek újra ellepik a méltán preferált turisztikai célpontokat. Ennek a tömegturizmusnak minden bizonnyal vége lesz egy időre. Mivel a járvány és ennek következtében kialakuló új higiéniai elöírások és utazási protokollok jelentősen megdrágítják az utazást és vendégfogadást. Ennek következtében elötérbe kerülhet a minőségi időtöltés, s ezzel együtt az egy helyben eltöltendő idő megnövekszik, amely minőségi szolgáltatásokat kíván meg a fogadó helyektől. A közlekedésben a zsúfoltság nem lesz fenntartható, ezért a fapados járatokat kiszorítják a prémiumkategóriás szolgáltatók, amelyek kevesebb személyt fognak utaztatni, de magasabb árért teszik ezt. Az utazás ismét a kiváltságosok privilégiuma lesz, mint ez volt nagyjából ötven-száz éve.

Minden bizonnyal azok a kormányzatok lesznek eredményesek, amelyek bátor lépésekre szánják el magukat, s ezeket képesek is elfogadtatni azzal a társadalommal, amelyért felelősséget vállaltak. A következmények nélküli vakmerőség épp úgy elvéti a célt, mint a hibásan elszámolt gyáva 
intézkedések. Azok a politikák élik túl a válságot, amelyek erős legitimitást tudhatnak maguk mögött és az intézkedéseik következménye ezt a legitimitást növelni tudja. Azok a kormányzatok erősödnek meg, amelyek a társadalmon belül tudják növelni a társadalmi rétegek közötti szolidaritást, így az idősek és fiatalok között, és ugyanakkor időben tudnak a nemzetközi térben együttmüködést kialakítani a járvány leküzdésében azonos érdekkel bíró partner államokkal. A belső kohéziót indokolja az a tény, hogy a járvány okozta válság különösen az időseket és a pályája elején álló fiatalokat sújtja. Az előbbieket azért, mert a járvány elsődlegesen az időseket tizedeli, az utóbbiakat pedig azért, mert a gazdasági krízis a megtakarítások nélküli belépő nemzedékek sorsát teszi kilátástalanná (Hunyadi és Molnár 2020). Az idős nemzedék a politika számára fontos, mert az ő szavazatai döntik el a választások sorsát, amíg az utóbbi nemzedék a gazdaság újra indításához nélkülözhetetlen erőforrás.

A nemzetközi politika terén a járvány a korábbi szövetségeket megerösítheti és gyengítheti, egy bizonyos eddigi rejtett kapcsolatokat felszínre hoz, s azok láthatóbbá vállnak. Ez mutatkozik meg az észak és dél közötti ellentét megnyilvánulásában az Európai Unión belül, ugyanakkor a kapcsolatok erősödése látványos a Közel-Keleti és Távol-Keleti együttműködések megerősödésében a járvány kezelése kapcsán (Kína és Izrael) de ugyanez tapasztalható a BRIC együttmüködés kapcsán is, amelyben a keleti országok (Kína, Oroszország) dinamizmusa világosan látszik Latin-Amerikában. A megerősödő nemzetközi hálózatok a korábbi piacok átrendeződését is elindíthatja.

3. A COVID-19 járvány okozta gazdasági válság lényegesen nagyobb hatással lehet a globális gazdasági rendszerekre, mint az a 2008-as pénzügyi válság utáni években volt. Egy éve arról írtam, hogy a Kondratyjev-ciklus végén kialakuló nagy struktúraváltás nem következhet be, mivel a korábbi hálózatok okozta útfüggőség ezt megakadályozza. Azt írtam, a válság majd egy lassú szemléletváltást indít el. Akkor még nem tudhattuk, hogy a járványnak a következő hullámai még erősebben gyürik majd maguk alá a gazdaság szereplőit (amelyet az állami intervenciók még most enyhítenek). A járvány okozta gazdasági visszaesést nem követte a várt visszapattanás, amely a korábbi évek gazdasági teljesítményét visszahozta volna. Még 2020 nyarán a Világ Bank 4,2 százalékos növekedést remélt a világgazdaság 
egészében 2021-re, ${ }^{8}$ azonban, a járvány második hulláma szétzúzta ezt a reményt. Minden bizonnyal mindennek változni kell ahhoz, hogy ne változzon semmi, azaz ha a korábbi elit meg akarja tartani korábbi pozícióit, ahhoz változtatnia kell a gazdaság korábbi szerkezetén. A változást a világgazdaság nem kerülheti el. Kína a szénalapú energia forrásait egy lépéssel a nukleáris és megújuló energia alapokra akarja helyezni. Az Egyesült Királyság, amely Európa egyik legjelentősebb földgázkitermelője, nyolc nukleáris megaerőmü megépítését indította el. Németország az Európai Unió tagállamait megelőzve a villamos energia termelésének nagy részét megújuló energiaforrásokra akarja helyezni. Az Egyesült Államokban a szénhidrogén lobbival együttmüködő korábbi elnök elvesztette a választást, amelyet minden bizonnyal a járvány és az ezzel kapcsolatos kampány erősen befolyásolt. Az új elnök, Joe Biden ígéretet tett, arra hogy visszahozza az USA-t a Párizsi protokollhoz (Dixon 2020). Az olajár világpiaci áresését Szaúd-Arábia az olajkitermelés radikális csökkentével állította meg 2021. év elején.

A globálisgazdaság jelentős átrendeződés elött áll, amelyben minden bizonnyal azok a régiók és országok kerülnek ki nyertesen, akik képesek változtatni a korábbi gazdasági szerkezetükön. A változás tengelyében az új energia és a kreatív tudás fog állni. Hogy ez az új gazdaság, amely szakítani képes a korábbi szénhidrogén alapú energiával, vajon milyen új nemzetközi hálózatokat épít, vagy épp a korábbi hálózatok mentén újul meg az még nem tudható. Az viszont sejthető, hogy a gazdaság átrendeződése a korábbi politikai gyakorlatokra hatással lesz, amely átrendezi a belpolitikák korábbi kánonjait is. A szénalapú gazdaság hanyatlása után (amelyet a nagy gazdasági világválság jelzett) jött létre a jóléti társadalom - a második világháború után, amelynek a gazdasága a szénhidrogénre épült. Lényegében ezt szimbolizálják a 20. század második felében az amerikai álom, a nyugat európai jóléti állam és a kelet európai szocialista rendszer társadalmi mintázatai. Ez a nagy gazdasági ciklus telítődési pontja a jóléti rendszerek válságának kezdete volt, ezt tapasztalhattuk a 1990-es évek elején. A válságot az ezredfordulót követő első pénzügyi sokk jelezte, amelyet nem követett gyors technológiai váltás, de elindultak az energiatermelésben azok a fejlesztések, amelyek a mostani válság után minden bizonnyal hatványozottan felgyorsulnak. A technológiaváltás a

\footnotetext{
${ }^{8}$ https://www.worldbank.org/en/news/feature/2020/06/08/the-global-economic-outlookduring-the-covid-19-pandemic-a-changed-world
} 
gazdaság szereplöi között is változást idézhet elö, amely hatással lesz a politikaformálásra is.

4. A jóléti rendszerek válsága (welfare) a jólléti rendszerek megerősödését (wellbeing) hozhatja magával. A tömegfogyasztást háttérbe szoríthatja a minőségi fogyasztás. Az egészség nem választható, hanem a túlélés lehetséges útja lesz. A járványkezelés és annak preventív módjai a társadalmakat rávezethetik a megelőzés olcsóbb és hatékonyabb módozataira. Háttérbe szorul a költséges kríziskezelés, amely nem lesz megfizethetö, s így nem lesz fenntartható. A tömegtársadalmak jóléti rendszerei elavulnak, nem lesznek költséghatékonyak. Mivel nem lehet hosszútávon tömeges intenzív ellátást biztosítani, ezért azok az egészségügyi rendszerek, amelyek ezeket nem haladják meg, olyan költségeket termelnek, amelyek az azt fenntartó államok eladósodásához vezetnek. Az eladósodás nem csak pénzügyi formában következik be, hanem a társadalmi költségek oldalán is jelentős társadalmi hiány képződik. A fellépő járványok a túlterhelt egészségügyi rendszer normál működését szétzilálják, kontraproduktívvá teszik. Így a hagyományos jóléti társadalomban az ellátatlan emberek hamarabb betegednek meg, a betegeket hamarabb veszítik el, ez a szociális rendszerben jelentkező diszfunkció a jóléti társadalmi rendszerek politikai legitimitását is kikezdi. A megoldást egy olyan politika adhatja, amelyben a hangsúly a mennyiség ellenében a minőség irányába tolódik el. A produktív jólléti politika a társadalom minőségét igyekszik emelni. Ez a társadalmi minőség olyan jólléti politikát támogat, amely az emberek jobb egészségét segíti elő a nevelés és oktatás, a családpolitika, a foglalkoztatás politika, ipar-és energiapolitika által. Azaz a hatalom, amely képes ezt felismerni, az egy tartós és fenntartható politikai rendszer alapját rakja le, ugyanakkor egy élhetőbb, minőségi társadalmat erősít meg. A társadalmi minőség új társadalmi szemléletet és új politikát követel meg (Lin - Herrmann eds. 2016), amelyben a környezeti tényezők felértékelődnek, az életmód és ezzel járó előnyök minőségi társadalmat teremtenek, melyben az egészségügy nem csak gyógyítással foglakozik, hanem a betegségek megelőzésével is. A járvány rámutatott a jóléti államok és abban élő társadalmak gyenge pontjaira. A jövőben a betegségmegelózés, amely az életmód és életkörülmények jobbításával érhető el prioritást kapnak, mivel ezek az eszközök még mindig hatékonyabbak, mint az akkut terápiás módszerek. A társadalmak védettebbek lehetnek a védőoltások mellett, ha azok tagjai egészségesebbek, 
így nem alakulnak ki a civilizációs betegségek, amelyet a mozgásszegénység, a stressz, az igénytelen táplálkozás, a környezeti ártalmak (légszennyezés, zajártalom, stb.), függőségek idéznek elö. A minőségi társadalomban az egyén felelössége növekszik önmaga és családja iránt, de a társadalomi szolidaritásnak is nagyobb szerep jut a gyermekek felnevelése terén.

\section{Konklúziók}

Összességében a COVID-19 minden tragédiája és borzalma ellenére lehetőséget is hordoz az Euro-atlanti tér országainak és társadalmainak, abban az esetben, ha tanulnak gyengeségeikből. Az elmúlt egy év tapasztalatai után nem lehetünk bizakodók. Az egészségügy még mindig ad hoc megoldásokkal próbál a járvánnyal szembeszállni az egyes országokban. Ezt a szektort kiszolgáló egészségipar eközben öldöklő és önző versenybe kezdett a piacokért, maximalizálva egy-egy tröszt saját nyereségét. A válságkezelő politikák nem harmonizálnak egymással, a gazdasági- és biztonságpolitikai együttmüködések nem váltották be a hozzá füzött reményeket, mivel a járvány elleni harc nemzeti, állami szinteken bontakozott ki és hozott megoldást. Lényegében a járvány okozta válságkezelésben nem hozott nyereséget egy tagállamnak sem. Az sem, ha az Európai Uniónak, vagy épp a NATO-nak volt tagja. Ellenkezőleg, az Európai Uniót elhagyó Egyesült Királyság járványkezelése sikeresebb volt valamennyi tagállamnál. A világgazdaságot nagyobb sokk érte, mint azt gondolta volna bárki, még 2020 tavaszán. Minden bizonnyal a helyreállítás már egy intenzív kreativ rombolás utáni korszakban indulhat be, amelyben több tényező megváltozhat, amelynek alapja - mint korábbi korszakváltások esetében is volt - az új energiaforrás megjelenése, illetve térhódítása. Az új energia új gazdasági ciklus kezdetét is jelzi, amelyben egy új minőségi társadalomra nyílik lehetőség. A korábban mennyiségi tényezőkre épített jóléti állam modellt felválthatja a jólléti társadalmak koncepciója, amelyben a szolidaritás és az együttmüködés és a minőség nem csak választható lesz, de a társdalom müködésének alapvető rendező elvei is lesznek. Az egyén számára az egészség nem pusztán választható életforma, de a túlélés alapvető formája lesz. Az egészségügyben a gyógyítás mellé felzárkózik a költséghatékony prevenció, amely új társadalmi minőséget, radikális változást generál. 


\section{Felhasznált irodalmak}

1. Arisztotelész (1987): Nikhomakhoszi etika. Budapest, Európa Könyvkiadó, 384.

2. Barabási, Albert-László (2018): Network science. Cambridge University Press.

3. Bódi, Ferenc (2020a): Courage in politics. In: eds. Bódi, Ferenc Ragusa, Andrea - Savova, Ralitsa, Courage in Politics. Pisa, Pacini Editore, 11- 24.

4. Bódi, Ferenc (2020). Engine of Hungary's development - Migration and Education politics in the 18th century and consequences for the modern age. Almanah Etnodialogi Moscow (61): 90-113.

5. Bódi, Ferenc (2014): Toward a dynamic theory of Local Organization of Social Services (LOSS) functioning. In: eds. Bódi, Ferenc - Fábián, Gergely - Fónai, Mihály - Kurkinen, Jorma - Lawson, R. Thomas Pietiläinen, Hannu, Access to Services in Rural Areas: A Comparison of Finland and Hungary. Bremen, Europäischer Hochschulverlag GmbH \& Co. KG, 4-26.

6. Bódi, Ferenc (2012): The development of the welfare system in Hungary (Historical background and national characteristic) In: eds. Bódi, Ferenc - Fábián, Gergely - Lawson, R. Thomas, Local Organization of Social Services in Hungary (Crises - Reactions Changes). Bremen, Europäischer Hochschulverlag GmbH \& Co. KG, 19-40.

7. Bródy András (2007): A ciklus oka és hatása. Közgazdasági Szemle (54) 10: 903-914.

8. Defoe, Daniel (1978): A londoni pestis. Budapest, Európa Könyvkiadó,

9. Dixon, Richard (2020): Joe Biden will bring US back into Paris Agreement on climate change as a state that believes science is important. The Scotsman. Monday, 16th November 2020

10. Ferguson, Niall (2011): Civilization: the West and the rest. New York, Penguin Press, 378.

11. Hunyadi Bulcsú - Molnár Csaba (2020): A koronavírus-járvány gazdasági és társadalmi következményei Józsefvárosban. FriedrichEbert-Stiftung - Political Capital, Budapest. p. 28. Letöltés helye: http://library.fes.de/pdf-files/bueros/budapest/16522.pdf 
12. Johnson, Niall P. A. S. - Mueller, Juergen D. (2002): "Updating the Accounts: Global Mortality of the 1918-1920 'Spanish' Influenza Pandemic“. Bulletin of the History of Medicine (76) 1: 105-115.

13. Lin, Ka - Herrmann, Peter eds. (2016): Social quality theory: a new perspective on social development. Oxford, New York, Berghahn Books.

14. Kosáry Domokos (1983): Művelődés a XVIII. századi Magyarországon. Budapest, Akadémiai Kiadó,

15. Kosáry Domokos (1991): Újjáépítés és polgárosodás 1711-1867. Budapest, Háttér Lap- és Könyvkiadó,

16. Le Goff, Jacques (2000): Az értelmiség a középkorban. Budapest, Osiris, 246.

17. Wellmann, Imre (1989): Magyarország népességének fejlődése a 18. században. In: (szerk.) Ember Győző - Heckenast, Gusztáv. Magyarország története 1686-1790. Budapest, Akadémia Kiadó, 25-80. 